\section{Sequence libraries}

SIR - Thank you for your article "Europe leads on sequences"' (Nature 15 April, p.596) on our efforts to establish a nucleotide sequence library. I welcome the attention given to the problems of data collection - a general discussion of these matters is both timely and important.

I do feel, however, that a few points require clarification. First, credit for the library at the European Molecular Biology Laboratory must also be given Kurt Stueber (of the Genetics Institute, Cologne), from whose collection we started, and who continues to work closely with us. Similarly, any discussion of nucleic acid sequence data collections in Europe must mention Professor Richard Grantham's group at Centre d'Evolution Moleculaire (Lyon),

who have run a large data bank for many years.

Although a central data library has yet to be established in the United States (later

this year according to NIH), several groups there have maintained large and excellent data bases for some time. The largest of these are the collections of Dr Walter Goad and his group at Los Alamos Scientific Laboratory, and Dr Margaret Dayhoff and her group at the National Biomedical Research Foundation (Georgetown).

This is not a case of "too many data banks'. The different approaches taken have each generated their share of good ideas, and if the present cooperative atmosphere can be maintained, a really excellent international resource combining the best ideas can result.

GREG HAMM

European Molecular Biology Laboratory, Heidelberg, FRG

\section{"Useless" research?}

SIR - Nature's leading articles show a persistent concern for the well-being of British universities, lately concentrating on research support and on the dual support system, at the expense of more important matters.

We are all concerned to protect research but I believe you seriously underestimate the resiliance of the British research effort and its supporters. The latter are strong, vocal advocates of their cause and I know of no good reason why we should be alarmed at this moment. Much of the fundamental research in question is expensive and in no way urgent. It will survive a little slowing down and a little less international competition.

Of much greater concern is the industrialeconomic basis of the country and the contribution to that basis which needs to be made by universities and, of course, by other agencies of higher education. In this context you mention (without, however, developing) the need for educational diversity. It is an essential requirement of any successful organization that it posses the highest degree of diversity compatible with its integrity. The model for a successful university system should be the usual model of any evolving system, namely a dynamic steady state stabilized in this case by the inevitable boundary conditions of budgets, standards and student numbers. It is essential that, within the system, there be both lateral and longitudinal flexibility in subject content and student effort. Such a pattern leads inevitably to the co-existence of broad degrees and specialized degrees, of vocational and nonvocational options, of universities and polytechnics, and of low level and high level exit qualifications. There needs to be a marked change in the emphasis of university teaching towards the Design-and-Make Society and I would remind you of the Royal Society of Arts initiative in support of Education for Capability.

There is nothing radically wrong with British universities that a little loosening up will not cure. The present financial crisis, for example, will be coped with readily if all those over 60 or, if necessary, over 55 will simply make way for the young and for any subsequent changes in subject emphasis deemed necessary. Making way does not imply "'walking the plank", but rather continuing one's vocation in teaching, research or both in retirement or semi-retirement. Some mortgaging of our financial future might still be necessary but not for long. Not every university can be saved an ugly confrontation in this way but the system as a whole could be. Since I am in favour of the present number of universities, a little more even spreading of the costs and the cuts would be entirely in order. Any suggestion that this would deprive us of necessary excellence is nonsense.

In winning back a little of the country's confidence in us, it would be as well not to go on supposing that our present arrangements are the best of all possibilities. A glance at France, Germany and the United States would convince many that this is not so.

The single honours degree is not the be-allend-all. For its own good, the dominating influence of Oxbridge and its concentration on scholarly excellence and other platonic virtues will have to be challenged by other equally exacting paths of excellence, paths of university study which also lead to competence and usefulness. If it is true that the annual toast of the Cambridge Philosophical Society is or was "Here's to our researches, may they always be useless!", is it surprising that our industries falter? This simplified analysis is no doubt open to criticism, but I shall be content if it stimulates discussion of ways forward rather than of defences of the status quo.

GRAHAM HiLls

University of Strathclyde Vice-Chancellor. University of Strathclyde,

Glasgow, UK

\section{Research accountant}

SIR - In an otherwise admirable article on current affairs and research at the Imperial Cancer Research Fund in Nature of 15 April 1982 (p.595), Robert Walgate is misleading in his interpretation of the accounts.

The income for the year ended 30 September 1981 is correctly stated to be $£ 17$ million, but $£ 12.8$ million ( 75 per cent) was spent on running the laboratories and extramural units, and $£ 803,389$ (4.7 per cent) on appeals, whilst a further $£ 2.7$ million ( 15.8 per cent) was spent on supporting the Liverpool cyclotron and trials with interferon. In addition we earmarked a sum of $£ 2.5$ million towards the cost of replacing the research laboratories that we shall lose when the Burtonhole Lane, Mill Hill premises revert to the MRC in 1986. A.B.L. Clarke

Imperial Cancer Research Fund, London WC2, UK

\section{Not all cranks}

SIR - In his review of Gardner's Science: Good, Bad and Bogus (Nature 28 January, p.351) Sir Peter Medawar asks "was it not Cuvier who named a fossil ichthyosaur as Homo diluvii testis - man-witness-of-theflood?".

No, it was not. And to make matters worse it was actually the good baron who showed the beast for what it was: a Miocene salamander. Later in his review, Medawar states "Not all scientific nonsense is written by cranks though: quite a lot of it is the work of scientists who . . . asseverate upon difficult subjects of which they have no deep understanding". Perhaps together with Medawar's "electrician-eugenicists" and "astronomer-microbiologists" we should include the immunologist-palaeontologist? Perhaps this is too harsh for I have no intention to Shock (ley) - it is just that Medawar has given little quarter to the many, doubtless deserving, persons who have come under his fire in the past and I only wish to see him play his own game according to Hoyle.

ANDREW FORESTER

Institute for Environmental Studies, University of Toronto, Canada

\section{April Fool!}

SIR - In your April Fool's Day issue, the article on pages 392-393 ends with the statement, "Long life is a fishy business indeed". There is more than long life that is "fishy" here. You have been caught in a pseudonym web again, although this time indirectly. The authors of the article from Acta Gerontol. (Prag.) are kidding somebody, as "Dlouhy-Zivot" means long life in Czech, and "Ryba" means fish. Anyway, hyphenated names in Czech are rare.

Frank A. Pitelka

University of California, Berkeley, USA

\section{Creative energy}

SIR - As a priest with a keen interest in astronomy and cosmology I have long pondered over the apparent contradiction to the second law of thermodynamics that is present in the standard big bang theory. I therefore read the paper "A model for the cosmic creation of nuclear energy"1 with much interest.

Having attempted to exorcize the notion of a literal interpretation to the opening chapters of Genesis, I was amused to read in the above article, 'We find that the main creation of nuclear energy started around $10 \mathrm{~s}$ after the big bang, and most of the exergy was created during the first few minutes, 85 per cent during the first hour, and that the process was essentially completed during the first $24 \mathrm{~h}$." Perhaps we also wish to add, "And there was evening and there was morning, one day."'!

"The first day of creation, who can act rationally on such a day!" - Alexander Solzhenitsyn.

The Chaplaincy,

GARTH BARBER

City of London Polytechnic,

London EI, UK

1. Eriksson, K.E. Islam, S. \& Skagerstam, B.S. Nature 296 540-541 (1982). 